\title{
Thermal Treatment and Mathematical Modeling of Tomato (Lycopersicon Esculentum Mill) Concentrate in Tin Container and Glass Container
}

\author{
Sebastian A. Lozano-Ayala \\ Haydee S. Huanca-Apaza \\ David Vivanco-Pezantes \\ Faculty of Fishing and Food Engineering \\ University National of Callao \\ Peru
}

\begin{abstract}
There's a deficiency in the application of the operational parameters on the pasteurized process for the food canning, resulting in products of low nutritional quality, this problematic leads to the need to establish optimization methods in the thermal treatment process. The research establishes the mathematical model as optimization method in the processing of semi-solids products analyzing at tomato puree in glass and tin container, under the following operation parameters: temperature and total solids concentration. The results and the behavior of the heating curve in the inside product are compared, and concluded that the lethal effects in both type containers secure the microbial inactivation and the minim nutritional degradation from the food components, and is greater that canned in glass container respect at tin container, this's because the thermal transfer constant and the material nature in the container.
\end{abstract}

Keywords: Thermal treatment, lethality, pasteurization, optimization, mathematical model.

\section{Introduction}

Actually the food industry of canning foods by heat, present the problematic in the disturbance of nutrients and organoleptic-physic characteristics, by submitting it to this condition, the following revision establish an optimization method of thermal treatment process in the pasteurization of canned tomato puree in glass container and tin container, and in consequence determinate the parameters of concentration solids total, pasteurization temperature and time in which it reaches the require lethally (value $\mathrm{P}_{0}$ ). For the optimization of heat process in high acidity products used the exponentials mathematical models because the treatment times are long and thus the error in the prediction of the initials temperatures don't have too much incidence in the calculation of the cumulative lethality, there is also a sigmoid model that predicts with great accuracy short process times as well as long times (Lespinard, 2010), in the research was tested with prime mater that present a pH between 4.1 to 4.4 where the proliferation mesophylls microorganism causes flat sour (Gómez-Sánchez, 2007), this bacterial nature makes the pasteurization application for the reduction of biological agents looking for the optimization of this process stage by determining a mathematical model that determines the time necessary of heat treatment, which must be submitted to the canned tomato puree in glass container with white cup and tin container, ensuring the microbial harmlessness and avoid the loss of characteristics organoleptic physics and nutritional properties because of the exposition to high temperatures, it has been realized similar researching, between are mentioned the obtaining of a sigmoid mathematical model for the precooking stage in fruits canning taking as answer parameter the cooking value in the treatment (Silva, 1997), as well as a comparative study of heat treatment optimization in whole tomato canning in glass container evaluating an exponential model and sigmoid model (Lespinard, 2010). In the researching gets two mathematical models no multivariable lineal, for the optimization of caned pasteurized processing tomato puree in glass container with white cup and tin container. Finally we have the researching make by (Gonzales, 2016) where finds the optimization of precooking process in tree tomato though the response surface principle, getting in this stage a reduction on the $10^{3} \mathrm{UFC} / \mathrm{g}$ y $10 \mathrm{UFC} / \mathrm{g}$ in mesophylls and mold / yeast respective, to temperature of $95^{\circ} \mathrm{C}$ for 5 minute of treatment, these parameters assure the color preservation increasing the antioxidant capacity of $\beta$-carotene. 


\section{Materials and Methods}

The use of tomato (lycopersicon esculentum mill) as study mater, was based in reference to the relative technology and making in the cultivate of this fruit, in last years, have been droving a technified irrigation that permits sow tomato for use industrial in open camp in the Peruvian coast (Numata, 2010) resulting in an increase of $17.41 \%$ in the last years (PRODUCE, 2015) generating the commercialization of derived products, presented mostly in paste and salsa, marketed in supple, tin and glass container with white cup. In each one the incidence of heat treatment vary agreement to the nature of material, whose thermal conductivity affect inthe calorific capacity supplied, thus in the researching opted for use the glass container and tin container, both with similar capacity of $400 \mathrm{ml}$, obtaining a mathematical model for type of container.

The prime matter was acquired from a local market where we used an approximated $90 \mathrm{~kg}$ of whole tomato for all experimental treatments and the glass container was acquired from the importing company "Soluciones de Empaque S.A.C." instead the tin container was manufactured by the company "Metalpren S.A.C.", we used 22 container of each material.

The treatment and measuring equipment were supplied by the Unitary Operations Laboratory of the Faculty of Fishing and Food Engineer at the University National of Callao, between which one mentions: An Electric vertical Autoclave from manufacturing national, a digital $\mathrm{pH}$ meter make HANNA instruments model HI8424, a Thermocouple temperature capture make RELES, a Digital scales, a Grams scales make AE ADAM model PW 254, a Manual seamer for tin container from manufacturing national, a Stainless steel support to the putting of signs to evaluate in the inside retort from manufacturing national, a Laptop make HP to register of temperature and calculation of accumulative lethality $\left(\mathrm{P}_{0}\right)$ in real time, a Refract meter make ATAGO model NAR-4T and an Stove make BINDER. The experimental procedure was given under the following criteria:

The operational parameters were established in the pasteurized process of tomato puree, determining the total solids concentration from puree and the pasteurizing temperature. The concentration ranges were obtained by preliminary tests in which a range of 7 to $24 \%$ was obtained, as operative rank in the concentrator equipment from laboratory (Simple concentration), this rank according to the normative by Codex Alimentarius for concentrated tomato (CODEX STAN 57-1981) obeys to puree. To establish the temperature range of the heat treatment it was necessary to know the nature of the objective microorganism present in the prime mater, at show a $\mathrm{pH}$ of high acidity $(4.1-4.4)$, where secures the proliferation no sporulans microorganism, from table 1 shows the aerobic thermophilic bacteria present responsible of flat sour and the bulging of canned products.

Table 1:Characteristics of contaminating microorganisms of high acidity foods

\begin{tabular}{|c|c|c|c|c|}
\hline Type of Microorganism & Name & Characteristic & Damage to Tin and Product & Foods \\
\hline \multirow[t]{2}{*}{ Sporing Forming Bacteria } & Bacillus thermoacidurans & Aerobic, thermophilic. & $\begin{array}{l}\text { Flat sour, little change in a vacuum, } \\
\text { light change in product's } \mathrm{pH} \text {, bad } \\
\text { smell and teste. }\end{array}$ & Tomato juice. \\
\hline & C. pasterianum & $\begin{array}{l}\text { Sporing forming, anaerobic, } \\
\text { sacarolytic, gas producer. }\end{array}$ & Can bulging. & \\
\hline Anaerobic Butiric Bacteria & & & $\begin{array}{l}\text { Can bulging. Fermented product with } \\
\text { butyric smell. }\end{array}$ & Tomato, tomato juice. \\
\hline Non-Sporing Forming Bacteria & Lactobacullus sp. & Some species are gas producer. & Can bulging. & \\
\hline Producers of Lactic Acid & leucomostoc sp. & $\begin{array}{l}\text { They develop better under } \\
\text { reduced oxygen tension }\end{array}$ & Acid smell of the product. & \\
\hline Yeast & & & $\begin{array}{l}\text { Infiltration of cooling water in the can } \\
\text { by micro rupture of this. }\end{array}$ & \\
\hline Molds & Byssochlamys fulva & $\begin{array}{l}\text { Causes rupture of pectin; gas } \\
\text { producer. Heat Resistant, } 30 \\
\text { minutes to } 190^{\circ} \mathrm{F} \text {, or } 16 \text { minutes } \\
\text { to } 212^{\circ} \mathrm{F} \text {. Recomended } \mathrm{D} \text { value: } \\
1 \text { a } 122^{2} \text { minutes to } 194^{\circ} \mathrm{F} \text {. }\end{array}$ & $\begin{array}{l}\text { In fruits causes the fruit to } \\
\text { desintegrate. }\end{array}$ & Canned fruits. \\
\hline
\end{tabular}

Source: Gomez-Sanchez, 2007. 
The Bacillus coagulans (Bacillus thermoacidurans) has more heat-resistant, thus the heat treatment will search the inactivation of this microorganism, that by its thermophilic mesophile nature is inactivated in a pasteurization process obtaining 6 logarithmic reductions respect to the initial population (Tucker, 2010), thus temperature ranges in the pasteurized was established between 70 to $100{ }^{\circ} \mathrm{C}$. Establish the heat treatment time was the response variable, regarding the permissible rank of accumulative lethality of process $\left(\mathrm{P}_{0}\right)$ is established in 1.0 5.0 minutes at the following thermal resistant values: $\mathrm{T}_{\text {ref }}=93.3^{\circ} \mathrm{C} \mathrm{y} \mathrm{z}=8.3^{\circ} \mathrm{C}$ (Eisner, 2010). Each one of the operative variables were evaluated of conjugated way, for each container type, in the pasteurized process obtaining as result the internal heating time of the product until get a lethality $\mathrm{P}_{0}=1$ minute, for being an optimization analysis where the heat transfer must be minimal, securing the product's harmlessness and the minim degradation of the nutrients. Of operatives variables ranges, established a factorial experimental design of centric and axial points, describe in the table 2, where obtained 11 experimental treatments for duplicated, for the heat treatment in glass container with white cup and tin container.

Table 2: Factorial experimental design with centric and axial points.

\begin{tabular}{ccccc}
\hline $\begin{array}{c}\text { Number of } \\
\text { Experimental Design }\end{array}$ & $\mathbf{X}_{\mathbf{1}}$ & $\mathbf{X}_{\mathbf{2}}$ & Concentration $\%\left(\mathbf{X}_{\mathbf{1}}\right)$ & Temperature ${ }^{\circ} \mathbf{C}\left(\mathbf{X}_{\mathbf{2}}\right)$ \\
\hline $\mathbf{1}$ & -1 & -1 & 9.47 & 74.4 \\
$\mathbf{2}$ & 1 & -1 & 21.53 & 74.4 \\
$\mathbf{3}$ & -1 & 1 & 9.47 & 95.6 \\
$\mathbf{4}$ & 1 & 1 & 21.53 & 95.6 \\
$\mathbf{5}$ & 0 & 0 & 15.5 & 85 \\
$\mathbf{6}$ & 0 & 0 & 15.5 & 85 \\
$\mathbf{7}$ & 0 & 0 & 15.5 & 85 \\
$\mathbf{8}$ & -1.41 & 0 & 7 & 85 \\
$\mathbf{9}$ & 1.41 & 0 & 24 & 85 \\
$\mathbf{1 0}$ & 0 & -1.41 & 15.5 & 70 \\
$\mathbf{1 1}$ & 0 & 1.41 & 15.5 & 100 \\
\hline
\end{tabular}

In each treatment obtained two product heating times in the autoclave until become the lethality $\mathrm{P}_{0}=1$ minute, in the heat treatment in glass container and tin container, the calculation of accumulative lethality $\left(\mathrm{P}_{0}\right)$ was determinate by the partial lethality's integral in the thermal process.

The Patashnik method facilitated the calculation of the integral. In the beginning of each experience measured the $\mathrm{pH}$ in the tomato puree, to validate the germination of objective pathogen microorganism, also the data were analyzed statistically in a process capacity analysis, using the MINITAB 15 , which resulted in a process capable of referring to the $\mathrm{pH}$ value for each treatment.

$$
P_{0}=\int_{0}^{t} L d t=\int_{0}^{t} 10^{\frac{\mathrm{T}-\mathrm{T}}{\mathrm{r}} \mathrm{z}} d t
$$

Where $\mathrm{L}$ is the partial lethality in the thermal process, $\mathrm{T}$ is the temperature from inside product during the pasteurization process, $\mathrm{T}_{\text {ref }} \mathrm{is}$ the referential temperature in the thermal process, $\mathrm{z}$ is the decimal reduction temperature of target microorganism and $t$ is the thermal process total time. The times obtained, were evaluated making use of non-lineal multivariable regression analysis, using the program STATISTICA 12, concluding previously in the statistic validity of the mathematic models. Of this obtained two response surface and two contort surface, for the thermal process in glass container and tin container. From this it was possible to determine the optima operating parameters for the thermal treatment process in each container type.

\section{Results}

Of the 11 experimental treatments analyzed in duplicate, obtained the heat times where the inside product reach an accumulative lethality $\left(\mathrm{P}_{0}\right)=1$ minute, in glass container with white cup and tin container, these are show in the table 3 . 
Table 3:Times obtained in the pasteurized process.

\begin{tabular}{ccccc}
\hline $\begin{array}{c}\text { Number of experimental } \\
\text { design }\end{array}$ & Concentration $\%\left(\mathbf{X}_{\mathbf{1}}\right)$ & Temperature ${ }^{\circ} \mathbf{C}\left(\mathbf{X}_{\mathbf{2}}\right)$ & \multicolumn{2}{c}{ Time required (minute) for the value $\mathbf{P}_{\mathbf{0}}=\mathbf{1}$ minute } \\
\hline $\mathbf{1}$ & 9.47 & 74.4 & 230 & Glass \\
$\mathbf{2}$ & 21.53 & 74.4 & 226 & 238 \\
$\mathbf{3}$ & 9.47 & 95.6 & 51.5 & 228 \\
$\mathbf{4}$ & 21.53 & 95.6 & 53 & 60 \\
$\mathbf{5}$ & 15.5 & 85 & 86 & 59.5 \\
$\mathbf{6}$ & 15.5 & 85 & 85 & 90 \\
$\mathbf{7}$ & 15.5 & 85 & 84 & 91 \\
$\mathbf{8}$ & 7 & 85 & 82 & 92 \\
$\mathbf{9}$ & 24 & 85 & 83 & 98 \\
$\mathbf{1 0}$ & 15.5 & 70 & 584 & 50 \\
$\mathbf{1 1}$ & 15.5 & 100 & 45.5 & 596 \\
\hline
\end{tabular}

From these obtained values, the interactions of the independent variables are calculated $(p>0,05)$, obtained determination coefficient of $88,4 \%$ and 87,92 for the thermal process in tin container and glass container respectively, confirming the explication of the response variable in the thermal treatment process. Agreement the ANOVA table showed in the table 4 and 5, for the thermal treatment in both container type, the calculated $\mathrm{F}$ values are shown, which are greater than the $\mathrm{F}$ of the table, therefore the mathematical model established is valid.

Table 4: ANOVA of the mathematical model of the response variable for heat treatment in tin container

\begin{tabular}{lcccc}
\hline Source of Variation & Quadratic Sum & $\begin{array}{c}\text { Number of Freedom } \\
\text { degrees }\end{array}$ & Half Quadratic & $\begin{array}{c}\text { Value F } \\
\text { calulated }\end{array}$ \\
\hline Regression & 22052.90 & 5 & 44810.580 & 7.958 \\
Dregs & 28155.10 & 5 & 5631.020 & \\
Lack of adjustment & 28153.10 & 3 & 9384.367 & 9384.37 \\
Pure Error & 2.00 & 2 & 1.000 & \\
\hline Total & 252208.00 & 10 & & \\
\hline
\end{tabular}

Table 5:ANOVA of the mathematical model of the response variable for heat treatment in glass container

\begin{tabular}{lcccc}
\hline Source of Variation & Quadratic Sum & $\begin{array}{c}\text { Number of Freedom } \\
\text { degrees }\end{array}$ & Half Quadratic & $\begin{array}{c}\text { Value F } \\
\text { calulated }\end{array}$ \\
\hline Regression & 225305.70 & 5 & 45061.140 & 7.281 \\
Dregs & 30944.70 & 5 & 6188.940 & \\
Lack of adjustment & 30942.70 & 3 & 10314.233 & 10314.23 \\
Pure Error & 2.00 & 2 & 1.000 & \\
\hline Total & 256250.40 & 10 & & \\
\hline
\end{tabular}

The mathematical model obtained responds to non-lineal multivariable equations. The equation 2 establish the pasteurized process in tin container:

$$
\begin{aligned}
\vartheta=85,235- & 0,137\left(\frac{C-15,5}{6,03}\right)-16,259\left(\frac{C-15,5}{6,03}\right)^{2}-139,262\left(\frac{T-85}{10,60}\right) \\
& +100,562\left(\frac{T-85}{10,60}\right)^{2}+1,375\left(\frac{C-15,5}{6,03}\right)\left(\frac{T-85}{10,60}\right)
\end{aligned}
$$

Of same way the equation 3 describes the pasteurized process in glass container with white cup: 28 


$$
\begin{aligned}
\vartheta=91,246-2 & , 731\left(\frac{C-15,5}{6,03}\right)-14,226\left(\frac{C-15,5}{6,03}\right)^{2}-140,492\left(\frac{T-85}{10,60}\right) \\
& +100,205\left(\frac{T-85}{10,60}\right)^{2}+2,375\left(\frac{C-15,5}{6,03}\right)\left(\frac{T-85}{10,60}\right)
\end{aligned}
$$

Where; $\vartheta$ is the pasteurized heating temperature until reach an accumulative lethality $\left(\mathrm{P}_{0}\right)$ de 1 minute, $\mathrm{C}$ is the total solids concentration of tomato puree and $\mathrm{T}$ is the pasteurized temperature. From these calculations the response surface is obtained, as can see in the graphic 1, is in form of chair point, for treatment in tin container and glass container with white cup.
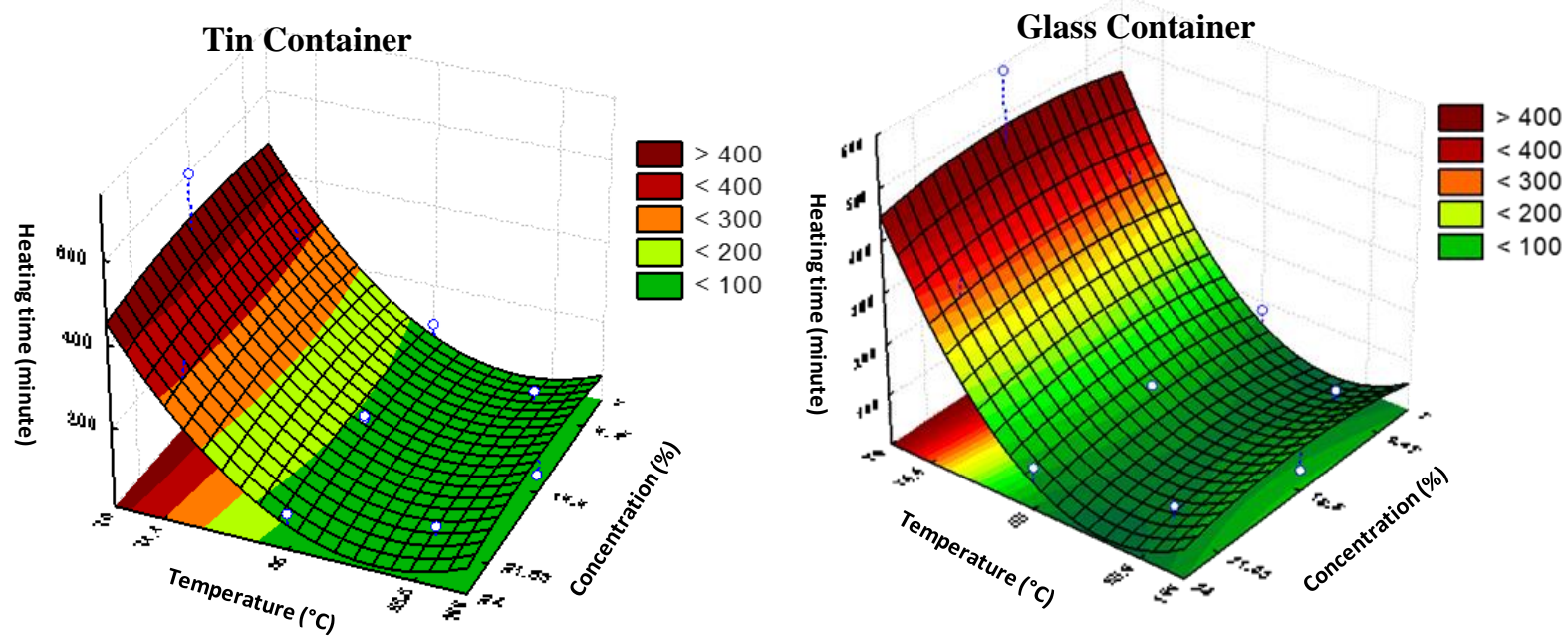

Graphic 1: Response Surface of heating time in the tomato puree at different concentrations (\%) and pasteurization temperature $\left({ }^{\circ} \mathbf{C}\right)$.

This also gives the Contour Surface, shown in graphic 2, where the formation of parallel lines slightly curved for the low temperatures experienced is observed, slightly different heating times are evidenced for the different concentrations tested.
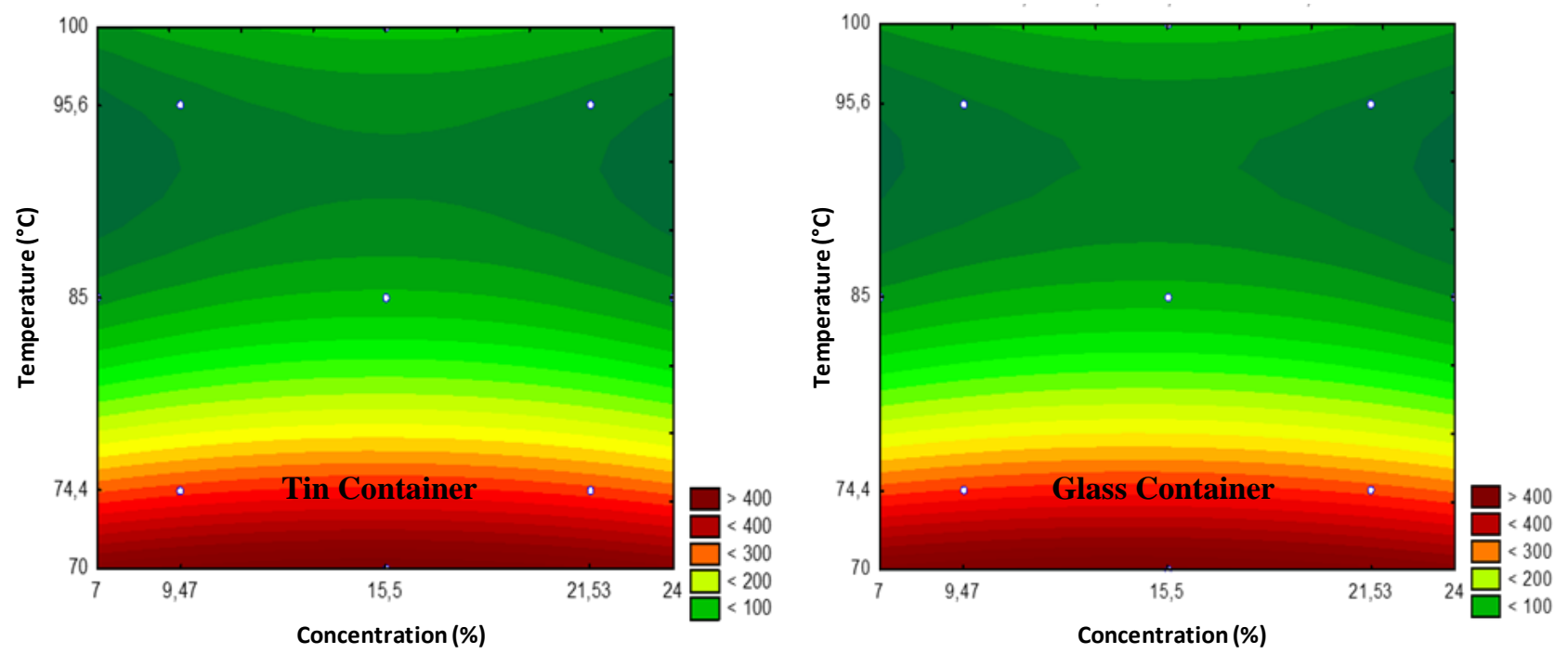

Graphic 2: Contour Surface of heating time in the tomato puree.

From the graphics established, obtained the thermal parameters in tin container: total solids concentration $15.65 \%$, temperature $92.34^{\circ} \mathrm{C}$ and a thermal treatment time 37.07 minutes. 
For the thermal treatment in glass container: total solids concentration $15.3 \%$, temperature $92.4^{\circ} \mathrm{C}$ and a thermal treatment time 42.02 minutes. The dates checked by validation experimental tested, whose results cans to see in the graphic 3 .
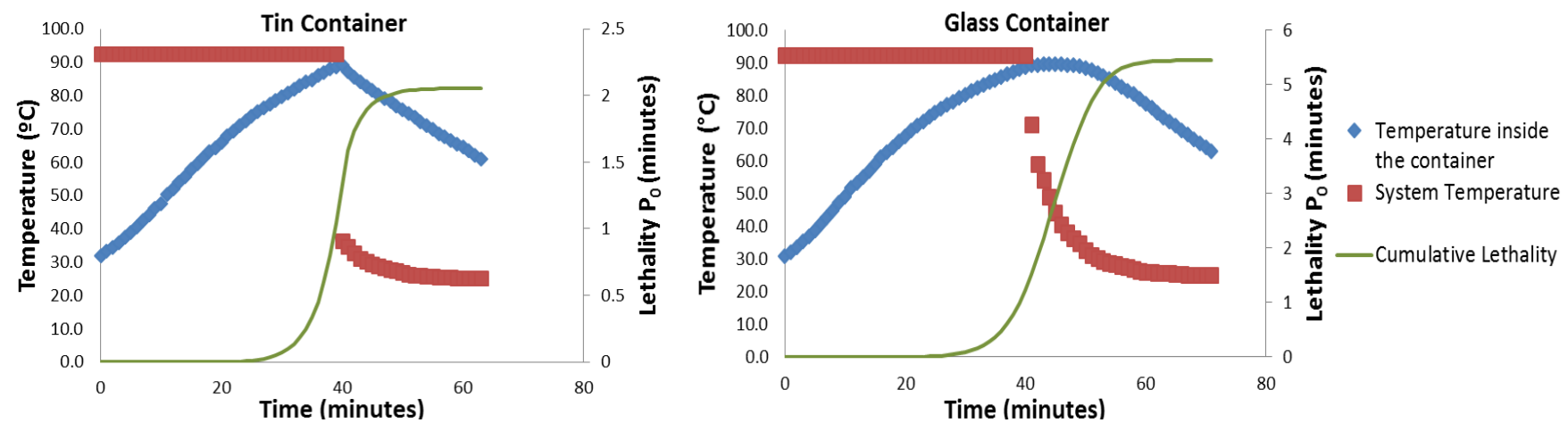

\section{Graphic 3:Heat penetration Curve and microbial lethality in the optima pasteurized process of tomato puree.}

Of the graphics, the obtaining of the optima times is observed of 39 and 40 minutes for the thermal treatment in tin container and glass container respectably, these are near according obtained by the mathematical model established from the no lineal multivariable regression.

Samples with the optima thermal process was send, to the laboratory quality control food, water and environment from the University National of San Marcos. Where the commercial sterility was determined, securing the absence of aerobic mesophylls microorganism and thermophile anaerobes. From the results obtained, the following is highlighted: the concentration variation from tomato puree doesn't influence of significantly way at process time, instead the pasteurized temperature's variation interferes in the global process's lethality $\mathrm{P}_{0}$ because the heat connective currents acquire more velocity when it's supplied more calorific capacity. So too the tridimensional distribution of chair point in the response surface, reflects that the tomato puree as it approaches its minimum concentration value tends to loss uniformity in its semi solid consistence forming more precipitation, this generates an increase in the inertia factor of the convective currents that is translated in a light increase of heat penetration time.

In all experiences the same tendency was observed, the heating time until reach the valor $\mathrm{P}_{0}=1$ minute, was more in the thermal process in glass container respect thermal process in tin container, because the glass presents less thermal transfer constant respect to the tin container. This factor makes the thermal process in glass container has a more lethal effect as holds more heat inside them thermal process, at the same time this more time in the glass container can causes physics organoleptic disturbance in the final product. While this researching focused in a product of determinate concentration whit a free convective transfer criterion, is feasible the implementation of others parameters that optimize more the process, in this case could apply the mechanism of axial agitation or vertical that generate a forced convective transfer.

\section{Conclusion}

The optima conditions of thermal treatment where assured the harmlessness and the less nutritional disturbance from tomato puree in tin container is a concentration in total solids of $15.65 \%$, a pasteurizing temperature of $92.34^{\circ} \mathrm{C}$ and a pasteurized time of 37.03 minute and in the glass container with white cup is a concentration in total solids of $15.30 \%$, a pasteurizing temperature of $92.40^{\circ} \mathrm{C}$ and a pasteurized time of 42.02 minute. The behavior and the tendency of the heating curve in the pasteurized process from the canned tomato puree in both container types were the same in each experimental treatment,needs more thermal treatment time in the canned in glass container with white cup compared to the canned in tin container to reach the $\mathrm{P}_{0}$ required.

\section{References}

CODEX ALIMENTARIUS.(1981). Norma del Codex para el concentrado de tomate elaborado. CODEX STAN 57. Available at http://www.fao.org/fao-who-codexalimentarius/es/. Accessed 2015-01-20.

Cornell, J. A. (2006). How to apply response surface methodology. Wisconsin: Editorial Wisconsin. Franco, D. (2009). Tomate industrializado. Alimentos Argentinos. Volumen (5): 26-31. 
Gomez-sanchez, A. I. (2007). Microorganismos de importancia en el tratamiento térmico ácidos y de alta acidez. Temas selectos de ingeniería de alimentos. Volume(1): 24-32.

González, D. (Ed.). (2016). Aplicación de un tratamiento térmico para el mejoramiento de la calidad microbiológica, física y funcional del tomate de árbol.Grupo de investigación en Ingeniería de alimentos GRIAL. Volume (2): 23.

Holdsworth, D. \&Simpson, R. (2007).Thermal processing of packaged foods. Washington: Editorial Springer Science.

Holdsworth, D. (1997). Thermal processing of packaged foods. London: Editorial Chapman Hall.

Lespinard, A. R.(2010).Simulación y optimización del tratamiento térmico de alimentos envasados en recipientes de vidrio.(Thesistooptthe Doctor degree). University National of La Plata, La Plata.

MINISTERIO DE LA PRODUCCIÓN. (2015). Reporte de producción manufacturera. Boletín de producción manufacturera.

Numata, K. (Ed.). (2010). Estudio sobre el caso de la producción creciente del tomate en los desiertos mediante el sistema agrario con poco insumo: desafíos en la zona costera del Perú. Estudio sobre el caso de la producción creciente del tomate en los desiertos mediante el sistema agrario con poco insumo. Volume (1): 1

Rodrigo, M. (Ed.). (1981). Optimización de las técnicas de esterilización por calor.Instituto de agroquímica y tecnología de alimentos. Volume(2): 20.

Sandoval, A. (Ed.). (2004). Prediction of hot-fill-air-cool sterilization processes for tomato paste in glass jars. Journal Food Engineering. Volume (23): 33-50.

Shafiur, M.\& Ahmed J. (2010). Food process desing. United Stated: Editorial Wiley-Blackwell.

Silva, F. (1997). Quality optimization of hot filed pasteurized fruit purees: container characteristics and filing temperatures. Journal of food Engineering. Volume (32): 351-364.

Tucker, G. (2010). Pasteurisation process designs. United Stated: Editorial Wiley-Blackwell.

Vives, E. (2009). Análisis de la capacidad del proceso. Available at http://docplayer.es/8318103-Tema-7-analisisde-la-capacidad-del-proceso.html.Accessed 2016-08-30. 